\title{
'Distance travelled versus the 'distance' travelled': enhancing the student learning experience using a creative and innovative approach to tutorial organisation
}

\author{
Dr Simon Brownhill \\ University of Cambridge, UK
}

\section{Abstract}

In an effort to remain both competitive and attractive to prospective and established students, higher education institutions, both at a national and international level, are actively seeking innovative ways of improving the experience, progression and retention of students (Jones, 2008). This paper reports on an original approach to tutorial organisation to enhance the learning experience of undergraduate students on a practice-based foundation degree at a university in the UK. Students' perceptions of tutorials prior to and post their active engagement with a classroom-based Tutorial Stations System (TSS) will be shared and discussed. Whilst there is a positive calling from students to sustain usage of the system as part of other taught modules on the programme, further research is needed to evaluate the impact of the system on helping to improve student attainment.

Keywords: tutorials; student experience; student learning; change.

\section{Introduction}

'In the late 20th century, changes in the UK and global economies meant that expanding post-compulsory education, particularly higher education, to meet the needs of the transforming economy became a preoccupation of government' (David et al., 2008, p.7). The resulting pressure and demands on academic staff to meet the diverse needs of an increasing student body has resulted in many seeking new and innovative ways to engage their learners with the intent of improving the quality of learning and teaching at university. From interactive lectures, engaging seminars and supportive workshops, to the utilisation of online materials, video supervision and contemporary social media (see Elavsky et al., 
2011), institutions in the UK are working hard, many in response to the National Student Survey (see http://tinyurl.com/2c76nm), to enhance the experience of an ever diverse cohort of students that will enable them to participate and achieve in the higher education arena (Thomas, 2011).

This paper considers the 'integral part' (Robinson, 2008, p.59) that tutorials play as part of taught modules on an undergraduate practice-based foundation degree (for information about foundation degrees see http://tinyurl.com/b9utz4e) at a university in the Midlands, UK, where the author previously worked. Whilst there are many definitions of the term 'tutorial' (see Herrmann, 2014), a tutorial within the context of this paper is defined as a short meeting (15-20 minutes duration) involving a teaching tutor with a small group of students (2-6) which aims to support them in the development of their assignment. Traditionally these tutorials take place over two consecutive weeks (one three hour session per week) following the taught input of the module (four taught sessions over four consecutive weeks, each session of three hours duration) to ensure that students are adequately prepared to engage in their module coursework (a 3000 word written assignment). During these tutorials, tutors ascertain the progress individual students are making with regard to writing their assignments, asking and answering questions relating to the module assessment. Student feedback from previous modules undertaken on the programme highlighted how many students perceived the distance they had to travel (the physical distance travelled), the monetary costs associated with this travel, and the time taken to reach the university for a '15 minute-tutorial-slot' as outweighing the actual value [academic progress made by students] of the tutorial attended (the progression 'distance' travelled). Additional concerns linked to pressures on finite resources in the University Library and effective (quiet) learning spaces for students to study in at the university resulted in the development of an innovative Tutorial Stations System (TSS) to positively address the areas of consideration identified above.

This paper reports on the use of the TSS as part of a research based taught module (entitled 'Research Methods and Practice') for full-time undergraduates in the second (final) year of their studies on the programme (Level 5). Funded by an internal Research for Learning and Teaching Fund (RLTF) bid in 2011/12, the paper will offer an explanation of the system, how it operates, and will reflect on the views of students who actively engaged with the system as part of the preparation work for their module assignment. 


\section{Review of literature}

Tutorials are considered to be a 'time-honoured feature of the university world' (Startup, 1977, p.192). Race (1989, cited Keddie and Trotter, 1998, p.172) describes the general purposes of a tutorial as giving students the chance to 'ask questions...encourage team working... [and]...give practice at making presentations'. This description is refined by Robinson (2008, p.59) who suggests that '[i]n an ideal form [tutorials are]...an effective way to create dialogue at an individual level between the student and a relevant staff member, in which learning requirements can be reviewed or identified, progress discussed, and future work planned'. The notion of 'learning' in Robinson's thinking is evident in the work of Dawson (1998, cited Sweeney et al., 2004, p.313) who suggests that tutorials are designed to complement classroom lectures, offering opportunities for learning (the progression 'distance' travelled) such as 'practising and applying concepts the students are learning and...checking the validity of their understanding through feedback and constructive criticism'.

Tutorials come in numerous forms, examples of which include face-to-face, distance (online), individual, group and workshop. (Readers are to note that the remainder of this review concerns itself with literature relating to tutorials that include several students). These are used in different ways by different institutions: for example, tutorials at the University of Cambridge (Palfreyman, 2008) and the University of Oxford 'are part of a learning system that usually involves students in a period of intensive individual study, the preparation of some work, whether an essay or completion of a problem sheet, followed by the tutorial [or supervision] itself' (Ashwin, 2006, p.652). In comparison, online tutorials at Universitas Terbuka in Indonesia are 'open throughout the semester so that students [can] post questions, comments, and responses to tutor's and others' questions at any time' (Belawati, 2005, p.18). There is an emphasis in the examples above on students demonstrating some kind of active engagement in the tutorial, be it prior to or actually during it. Jones (2010) supports this observation by suggesting that tutorials should purposefully encourage this participation. This mirrors the thinking of Gibbs (2010) who argues that being active in the process of learning helps to not only facilitate deep learning but is also a way of promoting more independent learning. An additional benefit to tutorial engagement is acknowledged by Divaharan and Atputhasamy (2002) who recognise that students can learn from one another, an opportunity which can be capitalised upon within the tutorial learning environment if promoted. 
Whilst there are seemingly many benefits associated with tutorial support, it is important to acknowledge some of the issues which surround their usage. For the purposes of this review four key issues will be highlighted. The first two issues presented below have been raised by teaching tutors who conduct tutorials; issues three and four are offered from the student perspective:

1. Poor participation: Marlina (2009) acknowledges how some students adopt a rather passive approach to tutorial participation, either sitting in silence or rarely volunteering an answer unless called upon to do so.

2. Poor attendance: Employment pressures are considered to be a key reason as to why students do not attend tutorials (Kottasz, 2005). Students who live 'far away' $(\mathrm{Ng}, 2007)$ (the physical distance travelled) may be reluctant to attend tutorials due to the cost and time implications.

3. Satisfaction rates: Douglas et al. (2006) and Stevenson and Sander (1998) highlight how some students are either 'not very' or 'not at all' satisfied with the overall provision made in terms of tutorial support they receive.

4. Student anxiety: It is suggested that students find tutorials intimidating (Takaesu et al., 2010) if they do not know their peers, do not respond well to their tutor, or do not appreciate the act of soliciting criticism and submitting their ideas to challenge (Petress, 1998) as supporting the learning process.

In order to make tutorials a more effective and positive experience for both students and tutors, numerous practical suggestions have been offered by academics to address the issues identified above. Webb (1980, p.20) suggests that '[t]he most effective way of increasing... participation rates of students in tutorials is for the tutor to absent himself from the discussion'. This is in direct opposition to the author's personal suggestion of planning for a variety of interactive activities to take place during it - the premise of the Tutorial Stations System - as opposed to the tutorial being overloaded with 'tutor talk' which is likely to result in student boredom. 'Correspondence (through postal services), mass media, radio and television broadcast and the Internet' are identified by Belawati (2005, p.16) as practical ways to overcome barriers which affect student attendance at tutorials, particularly those who are distance learners (thus positively addressing the issue of the physical distance travelled). Making tutorial attendance a compulsory element of studied 
modules is another possibility. In terms of addressing students' levels of satisfaction linked to tutorial support, allowing students to set the tutorial agenda ensures that they 'get what they want', content wise (thus positively addressing the issue of the progression 'distance' travelled). However, this does raise the question whether what students want from their tutorials is necessarily what they actually need; as such, Harris and Silva (1993, p.528) advocate an agenda which is 'negotiated' between the student and tutor. Hiola and Moss (1990, p.35) suggest that variations in tutorial time (duration), frequency of provision, tutorial group size, and access to tutorials are factors likely to positively influence students' attitudes towards tutorials. Embracing a pressure-less working environment, inviting students to contribute when they feel ready and willing to, and offering 'freedom, knowledge and autonomy' over proceedings (Shaw et al., 2008, p.712) are all further practical approaches tutors could embrace in an effort to reduce student anxiety during tutorials.

Unwin (1984, p.190) claims that 'a conscientious teacher can do a lot to improve tutorials'. Efforts to embrace this trait as a teaching tutor were utilised in the development of the Tutorial Stations System (TSS) to which the remainder of this paper is dedicated to. A full explanation of the TSS is offered as part of the Research Results (pages 7-13).

\section{The research aim and objectives}

The aim of the research was to critically evaluate the use of the TSS by exploring students' perceptions of the value and benefits of tutorials prior to and post their active engagement with the system as part of an undergraduate final year (Level 5) research-based taught module on a practice-based foundation degree. Sweeney et al. (2004, p.314) argue that 'very little research exists on students' perspectives on tutorials'; a subsidiary aim of the research was thus to address a need for research within this particular area of interest. Two objectives were used to drive the direction of the research:

1. To explore students' perceptions of tutorials as part of their learning experience on previously taught modules.

2. To evaluate the perceived 'preparedness' of students to undertake their module coursework following their active engagement with the TSS. 


\section{Research methodology}

The research embraced a mixed method approach (Tashakkori and Teddlie, 2010) in relation to the collection of the primary data, purposefully using 'converging lines of enquiry' (Yin, 2003, p.98) to explore and address the overall research aim and objectives. A staged approach, as advocated by Clough and Nutbrown (2011), was utilised as part of the research design:

Stage One: 54 semi-structured paper-based questionnaires were distributed to establish a pre-existing baseline of Level 5 (final year) students' perceptions of tutorials and their value as part of taught modules to date on their practice-based foundation degree (September 2011). The questionnaire contained a total of ten questions which utilised a range of question types to maintain respondents' interest. The piloted questionnaire took approximately 15 minutes to complete. Data generated from the questionnaire was both quantitative and qualitative in nature.

Stage Two: A non-participant observation of students was made of their engagement with both pre-existing arrangements for tutorials and the TSS (two observations in total) (November 2011). Both observations were 30 minutes in duration and were conducted using interval sampling. They were undertaken consecutively during the middle hour of the three hour period in which the pre-existing arrangements for tutorials and the TSS were timetabled.

Stage Three: Analysis of documentary evidence (in the form of module evaluation forms) was made to gauge students' perceived 'preparedness' to undertake their module coursework and their subsequent academic attainment (the progression 'distance' travelled) (November/December 2011). A total of four questions were included in the module evaluation form relating to the students' engagement with the TSS, gathering both quantitative and qualitative data.

Permission to undertake this research was initially sought and given in written form by the University Committee who awarded the author a successful internal RLTF bid. Ethical approval was also sought and given in written form by the University's Ethics Committee who offered suggestions to strengthen the ethical requirements of the research. Documentation of this approval may be requested from the author. The author's line 
manager at the time of the research being undertaken and the Programme Leader (the observer at Stage Two) of the foundation degree whose students would be taking part in the research, were both kept fully informed of the research from its conception to completion, providing valuable ethical oversight with regard to the processes adopted as and where appropriate.

\section{Research results}

\section{Stage One}

Full time undergraduate students in the second (final) year of their practice-based foundation degree were invited to complete a paper-based questionnaire about their perceptions and experiences of tutorials as part of their first year on the programme during their induction period in September 2011. The cohort (n54; 85\% female, 15\% male) were offered a piloted questionnaire which utilised a range of question types including list, dichotomous, category, ranking, scale and exact answers in an effort to engage and sustain respondent interest. A one-page covering letter served as a written vehicle for seeking informed consent. Assurances of student confidentiality and anonymity were detailed in the letter. Copies of this may be requested from the author. All students willingly completed the questionnaire during the induction period (n54, 100\% return). The questionnaire was administered by two colleagues as the author was unable to distribute these on the induction day; the author fully briefed (verbally) the two colleagues prior to the questionnaires being administered. Select findings generated from these questionnaires are offered below:

- Only 52\% (n28) of the cohort (n54) had attended all six of the tutorials offered to them in the previous academic year (one tutorial being offered for each of the six modules the students had studied at Level 4 (their first year of study)).

- The tutorials students had attended in the previous academic year were typically conducted in either small groups (made up of three to four students) or individually.

- On average $60 \%$ of the tutorials students had attended in the previous academic year lasted between 10-15 minutes.

$61 \%$ (n33) of students indicated that they were able to access other activities in the teaching room used for their tutorial, along with a face-to-face discussion with their 
teaching tutor. When asked to identify three of these 'other activities' students acknowledged the following as the three most prominent activities:

\section{Questions and Answers}

2. Help with my assignment

3. Looking at past assignments.

In the questionnaire students were asked to indicate whether they agreed or disagreed with a series of statements relating to the perceived value of tutorials. Select findings are presented in Table 1:

Table 1. Table to show the percentage of student agreement with select statements about the perceived value of tutorials.

\begin{tabular}{|l|l|}
\hline Statement & $\begin{array}{l}\text { Percentage of students (n54) in } \\
\text { agreement with the statement } \\
\text { (number of students) }\end{array}$ \\
\hline $\begin{array}{l}\text { Tutorials support me in improving my } \\
\text { grades }\end{array}$ & $87 \%(\mathrm{n} 47)$ \\
\hline $\begin{array}{l}\text { Tutorials are valuable to my learning } \\
\text { experience on taught modules }\end{array}$ & $77 \%(\mathrm{n} 42)$ \\
\hline $\begin{array}{l}\text { Tutorials give me confidence to write my } \\
\text { module assignment }\end{array}$ & $72 \%(\mathrm{n} 39)$ \\
\hline
\end{tabular}

There was variance in student thinking related to the best way of conducting tutorials; just over two thirds of respondents $(69 \%, \mathrm{n} 37)$ agreed that 'tutorials should be conducted in a group', whilst only $50 \%$ (n27) of students felt that 'tutorials worked best when they are conducted privately'.

Students were finally invited to identify from a range of practical suggestions what they personally wanted to be included during a tutorial. The three most prominent responses are presented in Table 2: 
Table 2. Table to show the percentage of students identifying practical suggestions for inclusion in a tutorial.

\begin{tabular}{|l|l|}
\hline Practical suggestion & $\begin{array}{l}\text { Percentage of students (n54) } \\
\text { identifying the suggestion } \\
\text { for inclusion in a tutorial } \\
\text { (number of students) }\end{array}$ \\
\hline $\begin{array}{l}\text { Looking at past assignments for the } \\
\text { module }\end{array}$ & $85 \%(\mathrm{n} 46)$ \\
\hline Individual time with the teaching tutor & $76 \%(\mathrm{n} 41)$ \\
\hline Reviewing referencing guidance/advice & $69 \%(\mathrm{n} 37)$ \\
\hline
\end{tabular}

\section{Stage Two}

Tutorials for the research based module took place in November 2011 following the taught input for the module by two tutors who each taught one of two separate teaching groups (n27 in each group). Due to staff illness only one of the two timetabled tutorial sessions assigned to the module was delivered (referred to as 'Tutorial Two'). One tutor conducted pre-existing arrangements for tutorial support (see page 2) with their group (referred to for the purposes of this paper as 'Group B'). This was conducted in the room where the taught input for Group B had been delivered. The other tutor [the author] secured the use of a new learning space in the form of a freshly designed teaching room in the university to conduct the TSS in an effort to enrich the student learning experience of his group (referred to for the purposes of this paper as 'Group A'). This room, decorated in a vibrant colour scheme, consisted of moveable tables and chairs, collaborative computer stations and glass writing walls. Various tutorial 'stations' were set up around the room by the author; these are identified and described in Table 3: 
Table 3. Description of the Tutorial Stations.

\begin{tabular}{|c|c|}
\hline Tutorial Station & Details \\
\hline $\begin{array}{l}\text { Face-to-face tutorial } \\
\text { with tutor }\left[1^{\star}\right]\end{array}$ & $\begin{array}{l}\text { Students attended group tutorials which they had signed up to a } \\
\text { week prior to the TSS being utilised. Students were asked to } \\
\text { take ownership of their tutorial agenda prior to attending it, } \\
\text { discussing things with their teaching tutor that they wanted to in } \\
\text { relation to the module, their handbooks and their coursework. } \\
\text { This was the only station that was staffed (by the author as a } \\
\text { teaching tutor). }\end{array}$ \\
\hline $\begin{array}{l}\text { Previous } \\
\text { assignments [2] }\end{array}$ & $\begin{array}{l}\text { Students had access to a selection of anonymised assignments } \\
\text { from previous cohorts pertinent to the module being taught. The } \\
\text { author had collected written permission from previous students } \\
\text { (by e-mail, seven in total) to allow their work to be seen by } \\
\text { others. All written feedback (both formative and summative) } \\
\text { which appeared on the assignments had been removed } \\
\text { electronically prior to them being made available to the current } \\
\text { cohort in paper form. } \\
\text { Students were not allowed to take images of the assignments } \\
\text { with their camera phones, nor were they allowed to make any } \\
\text { written notes when engaging with this station. Verbal reminders } \\
\text { were firmly shared with all students prior to accessing this } \\
\text { station and written reminders were clearly presented around this } \\
\text { station. }\end{array}$ \\
\hline $\begin{array}{l}\text { Academic literature } \\
\text { [3] }\end{array}$ & $\begin{array}{l}\text { Students had access to a range of academic literature (in the } \\
\text { form of both academic and professional books) sought from the } \\
\text { University Library relating to research methods. In consultation }\end{array}$ \\
\hline
\end{tabular}




\begin{tabular}{|l|l|}
\hline & $\begin{array}{l}\text { with a librarian, the literature was carefully selected in response } \\
\text { to the academic and professional needs of the students. } \\
\text { Computers in the teaching room were also made available for } \\
\text { students to access e-materials (internet based/electronic } \\
\text { journals/materials from the online learning platform) in relation to } \\
\text { research methods. }\end{array}$ \\
\hline Discussion area [4] & $\begin{array}{l}\text { Students were encouraged to use this area to openly discuss } \\
\text { the work for their assignment with their peers. }\end{array}$ \\
\hline $\begin{array}{l}\text { Private study area } \\
\text { [5] }\end{array}$ & $\begin{array}{l}\text { Students were encouraged to use this area to engage in their } \\
\text { own private study, be it individual or collaborative. }\end{array}$ \\
\hline
\end{tabular}

*See Figure 1 for a labelled 'visual' of the Tutorial Stations System 'in action'.

Due to the resource-dependent nature of several of the stations (stations 2 and 3), time consuming preparations were necessary to both prepare and organise support materials and the teaching room.

In an effort to positively address the issue of the physical distance travelled by students, all of the stations were made available for a three hour period following a peer assessed task which formed part of the module assessment. Students were free to engage with any of the stations available for as long as they wished; the only station which was 'time bound' was the Face-to-face tutorial with tutor station (timetabled tutorial slots of 20 minutes had been signed up for by students the previous week in the author's absence).

Students attended these tutorials in groups of between two and four; due to the class size it was not possible for the author [serving as the teaching tutor] to see students on an individual basis in the time available. Non-participant observations (30 minutes each) were undertaken by a supportive colleague (the Programme Leader of the foundation degree) whereby an interval sampling approach was utilised to gain an overview of proceedings (pre-existing arrangements for tutorials first and then the TSS). Permission from the students to be observed was verbally sought prior to each of the observations taking place. Select findings from the observation of the TSS highlighted that: 
- Many students chose to select a space in the room from which they engaged with the different stations, either taking samples of materials from each station to their working space or asking passing peers to collect materials for them.

- Some students chose to leave the tutorial room to collect refreshments, returning with these and consuming them as they engaged with the different stations.

- It was observed that 'there was a really calm, productive feel in the room' (observer's written comment).

Figure 1. The Tutorial Stations System 'in action'.

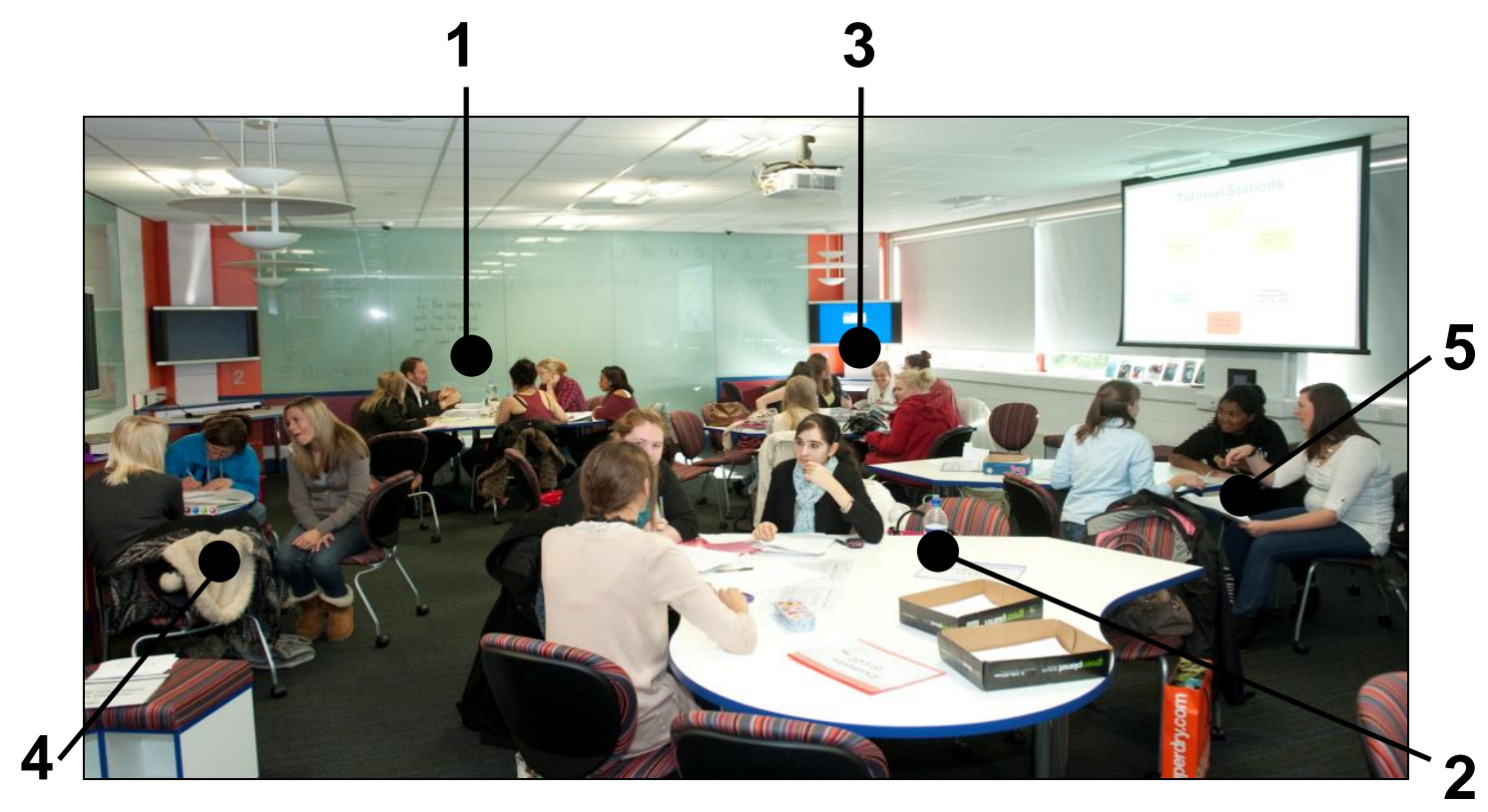

Permission sought for use (Simon Brownhill)

\section{Stage Three}

During their engagement with the TSS, students were asked to complete an anonymous end-of-module evaluation form. The form was an amended version of the standard one used for all of the taught modules on the programme; this was so that information could be gathered to gauge students' thoughts about the TSS and to see if it had positively addressed the issue of the progression 'distance' travelled that had been highlighted by students in previous module feedback (see page 2). The form took approximately ten minutes to complete. Of those students fully completing the module evaluation form (n16), the following findings presented in Table 4 were considered significant: 
Table 4: Table to show significant findings from the module evaluation form about the TSS and the associated percentage of students.

\begin{tabular}{|l|l|}
\hline Finding & $\begin{array}{l}\text { Percentage of students } \\
\text { (n16) (number of } \\
\text { students) }\end{array}$ \\
\hline $\begin{array}{l}\text { Students accessed the TSS for an hour or } \\
\text { more }\end{array}$ & $82 \%(\mathrm{n} 13)$ \\
\hline $\begin{array}{l}\text { Students found the TSS to be valuable to their } \\
\text { learning experience on the module }\end{array}$ & $100 \%(\mathrm{n} 16)$ \\
\hline $\begin{array}{l}\text { Students felt 'well prepared' or 'very prepared' } \\
\text { for the writing of their assignment following the } \\
\text { taught input and the TSS }\end{array}$ & $\begin{array}{l}82 \%(\mathrm{n} 13) \\
\text { ('well prepared' (57\%, n9); } \\
\text { 'very prepared' (25\%, n4)) }\end{array}$ \\
\hline
\end{tabular}

A small number of students ( $n 4)$ offered written comments about the TSS on their amended module evaluation form:

The development of the tutorial stations - the availability of books, previous assignments and [teaching tutor's name] was valuable in developing the learning outcomes better and ensuring we knew what was expected. As other students stayed, it encouraged lots of others to stay too.

Face to face tutorial helped me with assignment and [there] were different stations which helped me a lot too.

Good use of different stations.

To keep using the tutorial station method. It was much much better than the previous method of 15 mins. 


\section{Discussion and conclusion}

In November 2011 students submitted their module coursework for assessment. It was personally felt that the TSS had been a success in relation to positively addressing the issues of the physical distance travelled by students and the progression 'distance' travelled in terms of the value [academic progress made by students] of the tutorial experienced, particularly when one took into consideration the student feedback (via the amended module evaluation forms) and informal discussions with the observer. However, the author was curious to determine the effects (if any) of the TSS on student attainment (the progression 'distance' travelled).

Module coursework was marked by the two tutors who had taught the module and led the subsequent tutorials (one tutor leading the pre-existing arrangements for tutorials, with the other tutor [the author] leading the TSS). Both tutors were experienced markers. Student achievement for the module was collated by the module leader (the author) in an effort to compare levels of attainment between the group who had experienced the TSS (Group A) and the group who had not (Group B). Analysis of student achievement highlighted that attainment was higher in the group that had not engaged with the TSS (Group B). Whilst the same number of $A$ and $F$ grades were obtained in both groups, a larger number of $B$ and $\mathrm{C}$ grades were achieved by students in the group who had experienced pre-existing arrangements for tutorial support (Group B).

Following this analysis, discussions with colleagues on the programme highlighted the need for further research to be undertaken to investigate the factors which may have influenced the grades attained by the two groups. Possible factors relate to the differing demographics of the two groups; these include more male learners in Group A as opposed to Group B, more mature students in Group B as opposed to Group A, and lower entry grades onto the programme of students in Group A as opposed to Group B.

By reflecting on the aim(s) and objectives set for the research undertaken, it can be acknowledged that the TSS was a successful venture. The system was effective in addressing known issues with tutorial provision: in terms of student participation, $100 \%$ of the group (Group A, n27) who were offered the TSS had travelled the physical distance to actively engage with it. It must be noted, however, that all students were already in attendance at the university due to the peer assessed task they had to complete prior to 
the TSS being made available to them. The system offered a substantial amount of time for students to engage with preparations for their module coursework, offering them a range of activities which both they and tutors felt would be valuable to their studies e.g. looking at previous assignments, time with the teaching tutor and reviewing referencing guidance/advice; this was largely facilitated through the face-to-face tutorials with students. Active participation was promoted through the different stations which were on offer, and satisfaction rates were positive in the percentage of students feeling 'well prepared' $(57 \%, \mathrm{n} 9)$ or 'very prepared' $(25 \%, \mathrm{n} 4)$ in terms of writing of their assignment following the taught input and the TSS (the progression 'distance' travelled). There was no evidence of student anxiety in terms of students engaging with the system from the perspective of the author, the observer (at Stage Two), or the students themselves.

Whilst favourable comments have been offered by students to use the system in other modules on the programme, and more recently from senior management at the university to whom this research was presented by the observer, it is felt that more research is needed to evaluate the impact of the TSS on the grade attainment of students (the progression 'distance' travelled), considering ways in which these could be improved as a result of students actively engaging with an amended version of the system. Practical strategies for amendment are currently being implemented and reviewed for discussion in a follow-up paper.

\section{Note}

Efforts to disseminate the findings of the research reported in this paper can be found in the form of an online poster - see http://tinyurl.com/kjeoaya

\section{References}

Ashwin, P. (2006) 'Variation in academics' accounts of tutorials', Studies in Higher Education, 31(6), pp. 651-665.

Belawati, T. (2005) 'The impact of online tutorials on course completion rates and student achievement', Learning, Media and Technology, 30(1), pp. 15-25. 
Clough, P. and Nutbrown, C. (2011) A student's guide to methodology: justifying enquiry. $3^{\text {rd }}$ edn. London: Sage.

David, M., Parry, G., Vignoles, A., Hayward, G., Williams, J, Crozier, G., Hockings, C. and Fuller, A. (2008) Widening participation in higher education: a commentary by the Teaching and Learning Research Programme, London: Teaching and Learning Research Programme.

Divaharan, S. and Atputhasamy, L. (2002) 'An attempt to enhance the quality of cooperative learning through peer assessment', Journal of Educational Enquiry, 3(2), pp. 72-82.

Douglas, J., Douglas, A. and Barnes, B. (2006) 'Measuring student satisfaction at a UK university', Quality Assurance in Education, 14(3), pp. 251-267.

Elavsky, C.M., Mislan, C. and Elavsky, S. (2011) 'When talking less is more: exploring outcomes of Twitter usage in the large-lecture hall', Learning, Media and Technology, 36(3), pp. 215-233.

Gibbs, G. (2010) Dimensions of quality. York: The Higher Education Academy.

Harris, M. and Silva, T. (1993) 'Tutoring ESL Students: Issues and Options', College Composition and Communication, 44(4), pp. 525-537.

Herrmann, K.J. (2014) 'Learning from tutorials: a qualitative study of approaches to learning and perceptions of tutorial interaction', Higher Education, February, DOI: 10.1007/s10734-014-9731-3.

Hiola, Y. and Moss, D. (1990) 'Student opinion of tutorial provision in the Universitas Terbuka of Indonesia', Open Learning: The Journal of Open, Distance and eLearning, 5(2), pp. 34-38.

Jones, A. (2010) Encouraging student participation in tutorials. Carlton 3053: The Teaching and Learning Unit, Faculty of Business and Economics, University of Melbourne. 
Jones, R. (2008) 'Student retention and success: a synthesis of Research', EvidenceNet, Higher Education Academy, pp. 1-43 [Online]. Available at:

http://www.heacademy.ac.uk/assets/EvidenceNet/Syntheses/wp retention synthesi

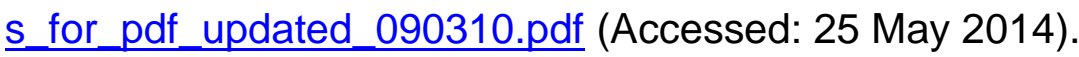

Keddie, J. and Trotter, E. (1998) 'TEACHING NOTE: Promoting participation-breathing new life into the old technology of a traditional tutorial: a teaching note', Accounting Education: An International Journal, 7(2), pp. 171-181.

Kottasz, R. (2005) 'Reasons for student non-attendance at lectures and tutorials: an analysis', Investigations in University Teaching and Learning, 2(2), pp. 5-16.

Marlina, R. (2009) “I don't talk or I decide not to talk? Is it my culture?' - International students' experiences of tutorial participation', International Journal of Educational Research, 48(4), pp. 235-244.

Ng, K. C. (2007) 'Replacing face-to-face tutorials by synchronous online technologies: challenges and pedagogical implications', The International Review of Research in Open and Distance Learning, 8(1), February [Online]. Available at: http://www.irrodl.org/index.php/irrodl/article/view/335/764 (Accessed: 25 May 2014).

Palfreyman, D. (2008) 'Higher education, liberal education, critical-thinking, academic discourse, and the Oxford tutorial as sacred cow or pedagogical gem', in Palfreyman, D. (ed.) The Oxford tutorial: 'thanks, you taught me how to think'. Oxford: OxCHEPS, pp.1-37.

Petress, K. (1998) 'Critical thinking: an extended definition', Education, 124(3), pp. 461466.

Robinson, S. (2008) 'Using a strategy of 'structured conversation' to enhance the quality of tutorial time', Journal of Further and Higher Education, 32(1), pp. 59-69. 
Shaw, L., Carey, P. and Mair, M. (2008) 'Studying interaction in undergraduate tutorials: results from a small-scale evaluation', Teaching in Higher Education, 13(6), pp. 703714.

Startup, R. (1977) 'Staff experience of lectures and tutorials', Studies in Higher Education, 2(2), pp. 191-201.

Stevenson, K. and Sander, P. (1998) 'How do Open University students expect to be taught at tutorials?', Open Learning, 13(2), pp. 42-46.

Sweeney, J., O'donoghue, T. and Whitehead, C. (2004) 'Traditional face-to-face and webbased tutorials: a study of university students' perspectives on the roles of tutorial participants', Teaching in Higher Education, 9(3), pp. 311-323.

Takaesu, A., Sudo, M. and Christianson, M. (2010) "Some tutorials were only scarily': students' perceptions of teacher-learner conferences within a Japanese university ELP program', Language Research Bulletin, 25, ICU, Tokyo, pp. 1-17 [Online]. Available at: http://web.icu.ac.jp//rb/docs/Takaesu-Sudo-ChristiansonLRB25I.pdf (Accessed: 25 May 2014).

Tashakkori, A. and Teddlie, C. (eds.) (2010) Handbook of mixed methods in social and behavioral research. $2^{\text {nd }}$ edn. Thousand Oaks, CA: Sage.

Thomas, L. (2011) 'Chapter 2: Engaging students to improve retention and success', in Thomas, L. and Tight, M. (eds.) Institutional transformation to engage a diverse student body. International perspectives on higher education research. Volume 6. Bingley: Emerald, pp. 41-55.

Unwin, D. (1984) 'Things I do badly: tutorials', Journal of Geography in Higher Education, 8(2), pp. 189-192.

Webb, G. (1980) 'Student participation in tutorials', Journal of Geography in Higher Education, 4(1), pp. 16-22.

Yin, R.K. (2003) Case study research design and methods. London: Sage Publications. 


\section{Author details}

Dr Simon Brownhill is a Senior Teaching Associate in the Faculty of Education at the University of Cambridge, working on the Kazakhstan Project as part of the International Educational Development Programmes. He was previously a Senior Lecturer at the University of Derby where he taught on a range of undergraduate and postgraduate education-based programmes. His research interests include children's story writing, creative learning and teaching in the classroom, international perspectives on reflective practice, children's behaviour management, children's physical development, and the male role model in the early years (0-8) (the focus of his doctoral thesis). 